\section{Sprawozdanie \\ z XIII międzynarodowej konferencji naukowej $z$ cyklu \\ „Europa XXI wieku. Europa i Unia \\ Europejska wobec kryzysu. \\ Diagnoza, rozwiązania \\ i scenariusze na przyszłość"}

(Collegium Polonicum, 7-8 lutego 2013 r.)
W dniach 7-8 lutego Wydział Nauk Politycznych i Dziennikarstwa Uniwersytetu im. Adama Mickiewicza w Poznaniu zorganizował XIII konferencje z cyklu Europa XXI wieku, która odbyła się w Słubicach w Collegium Polonicum - wspólnej placówce naukowo-badawczej Uniwersytetu im. Adama Mickiewicza w Poznaniu oraz Uniwersytetu Europejskiego Viadrina we Frankfurcie nad Odra. Tegoroczna konferencja zatytułowana była „Europa i Unia Europejska wobec kryzysu. Diagnoza, rozwiązania i scenariusze na przyszłość" i podobnie jak ubiegłoroczna - poświęcona była tematyce kryzysu, który dotknął nie tylko Europe jako kontynent, ale przede wszystkim Unię Europejską. Konferencję wsparło troje partnerów: Przedstawicielstwo Komisji Europejskiej w Polsce oraz Fundacja Konrada Adenauera, a także Ambasada Konfederacji Szwajcarskiej w Warszawie.

Tegoroczna konferencja Europa XXI wie$k u$ stworzyła sposobność do wymiany opinii i poglądów oraz prezentacji wyników badań na temat współczesnych problemów starego kontynentu, w tym zjawisk będących konsekwencjami kryzysu gospodarczego, który okazał się dla UE sprawdzianem trwałości jej struktur, efektywności mechanizmów i procedur działania. Kryzys finansowy oraz jego konsekwencje zauważalne są praktycznie w każdym z państw członkowskich Unii, a jego konsekwencje są na tyle poważne, iż zasadne jest stawianie dziś pytań o jego wpływ na polityczną i ekonomiczną przyszłość integracji europejskiej.

Celem konferencji było zatem między innymi, ukazanie determinantów ról i znacze- nia Unii Europejskiej w gospodarce światowej i współpracy międzynarodowej, wpływu kryzysu zadłużeniowego niektórych państw członkowskich na obecną i przyszłą kondycję Unii Gospodarczej i Walutowej, przyczyn problemów Eurolandu i ich wpływu na rozwój współpracy w ramach UE, perspektyw dalszego poszerzania Unii Europejskiej, możliwości zachowania starych lub powstania nowych podziałów w Europie i samej UE, znaczenia ponadnarodowych grup interesów w powstaniu i przezwyciężaniu kryzysu, wpływu kryzysu na bezpieczeństwo państw i obywateli UE w różnych jego wymiarach, nowych ruchów społecznych jako konsekwencji problemów ekonomicznych i pogłębienia zróżnicowania socjalnego społeczeństw, roli środków społecznego przekazu w popularyzacji idei integracji europejskiej, kreowaniu wizerunku organizacji i instytucji europejskich oraz przezwyciężaniu skutków kryzysu, barier i uwarunkowań rozwoju Europy i Unii Europejskiej w obliczu rosnącej konkurencji na rynkach międzynarodowych, pożądanych i możliwych kierunków zmian w systemie prawnym i instytucjonalnym UE w obliczu nowych zagrożeń oraz związane z tym zadania dla polityków, naukowców, mediów i dziennikarzy.

Godnym zauważenia jest fakt, iż tegoroczna konferencja była największą pod względem liczby uczestników spośród wszystkich trzynastu konferencji słubickich. W tym roku organizatorzy gościli około 270 osób. Wśród nich byli nie tylko naukowcy z różnych ośrodków akademickich w Polsce, ale także badacze, praktycy, dziennikarze, politycy oraz 
eksperci między innymi z Niemiec, Szwecji, Danii, Finlandii, Cypru, Szwajcarii, Ukrainy, Rosji czy Kazachstanu. Nadmienić należy, iż oprócz znamienitych gości ze środowiska naukowego, do Słubic przyjechali przedstawiciele m.in. Komisji Europejskiej, Ambasady Szwajcarskiej czy Ambasady Republiki Kazachstanu.

W trakcie dwudniowej konferencji Europa XXI wieku. Europa i Unia Europejska wobec kryzysu. Diagnoza, rozwiazania i scenariusze na przyszłość odbyły się obrady plenarne oraz dwadzieścia trzy panele tematyczne, w tym dwa anglojęzyczne i jeden rosyjskojęzyczny. Pierwszego dnia konferencji odbyło się ponadto posiedzenie Zarządu Głównego Polskiego Towarzystwa Nauk Politycznych.

Konferencję otworzył Dziekan Wydziału Nauk Politycznych i Dziennikarstwa UAM prof. dr hab. Tadeusz Wallas, który w swym wystąpieniu zwrócił szczególną uwagę na aktualność tematów podejmowanych na konferencji. Dyrektor Przedstawicielstwa KE w Polsce - dr Ewa Synowiec - w swoim przemówieniu podkreśliła, że ostatnie lata to czas bezprecedensowych reform w Unii Europejskiej. Zwróciła przy tym uwagę, że z obrazu Europy, który wyłania się po kryzysie, wynikają istotne pytania dla Polski i jej roli w nowej Unii Europejskiej. W tej części obrad planarnych głos zabrał również prof. dr hab. Roman Bäcker - Prezes Polskiego Towarzystwa Nauk Politycznych, który zaznaczył ważną rolę konferencji Europa XXI wie$k u$ dla środowiska politologów i europeistów w Polsce.

W czasie obrad plenarnych wygłoszono dziewięć referatów. Pierwsze wystapienie - autorstwa prof. Jensa Lowitzscha z Uniwersytetu Europejskiego Viadrina we Frankfurcie nad Odrą - dotyczyło szczególnego instrumentu zwalczania kryzysu ekonomicznego - Employees Financial Participation. Prof. dr hab. Konstanty A. Wojtaszczyk z Uniwersytetu Warszawskiego zaprezentował referat pt. Przeobrażenia ustrojowe Unii Europejskiej z perspektywy zjawisk kryzyso- wych, natomiast prof. dr hab. Bogdan Koszel z Uniwersytetu im. Adama Mickiewicza w Poznaniu swoje wystapienie poświęcił tematowi roli Niemiec w przezwyciężaniu kryzysu finansowego strefy euro. Ostatnim prelegentem w pierwszej części obrad plenarnych był prof. dr hab. Janusz Węc z Uniwersytetu Jagiellońskiego, który wygłosił referat pt. Debata w Unii Europejskiej na temat drugiej reformy ustrojowej (2011-2012).

W drugiej części obrad plenarnych wygłoszono pięć referatów. Prof. dr hab. Wiesław Bokajło, reprezentujący Uniwersytet Wrocławski, mówił o Unii Europejskiej w kontekście deficytu demokracji i oligarchizacji władzy, prof. Kaken Kamzin z Kazachstanu (Al-Farabi Kazakh National University) wygłosił referat pt. The news set of modern journalism, prof. dr hab. Teresa Łoś-Nowak z Uniwersytetu Wrocławskiego rozważała pozycję państwa narodowego w Unii Europejskiej w kontekście zjawisk autonomii, asymilacji i adaptacji, natomiast prof. Volodymyr Yemelyanov z ukraińskiego Uniwersytetu Państwowego im. Petra Mogyły wygłosił referat pt. Rozwój biznesu Ukrainy w umowach konkurencji globalnej. Tę część konferencji zakończyło wystąpienie prof. dr hab. Ryszarda Zięby z Uniwersytetu Warszawskiego, który przedstawił scenariusze na przyszłość Unii Europejskiej w warunkach kryzysu. Sesję planarną zamknęła dyskusja.

Pierwszego dnia konferencji obrady kontynuowano $\mathrm{w}$ jedenastu sesjach tematycznych poświęconych przede wszystkim kryzysowi w Europie, ale także demokracji w Unii Europejskiej, kwestiom społecznym, roli Polski w Unii, a także wschodnim sąsiadom UE. W panelach poruszano także tematykę mediów w Europie i próbowano podsumować obraz polskiej prezydencji w Radzie Unii Europejskiej. W tej części znalazł się panel anglojęzyczny poświęcony europejskim eksklawom oraz thumaczony na język angielski panel dotyczący stosunków Szwajcarii $\mathrm{z}$ UE. Warto nadmienić, iż dzięki uprzejmości Ambasadora Szwajcarii Lukasa 
Beglingera, który objął honorowym patronatem właśnie panel poświęcony europejskiej polityce Szwajcarii, konferencji towarzyszyła wystawa poświęcona szwajcarskiej demokracji bezpośredniej oraz relacjom pomiędzy federacją helwecką a Unią Europejską.

Drugiego dnia konferencji odbyło się łącznie szesnaście sesji tematycznych: oprócz kontynuacji obrad w rozpoczętych poprzedniego dnia czterech panelach (dotyczących kwestii społecznych, roli Polski w UE, Partnerstwa Wschodniego i kryzysu w mediach), rozpoczęto obrady w kolejnych dwunastu. Dotyczyły one m.in. takich problemów, jak: polityka UE w dobie kryzysu, rola Niemiec w UE, relacje zewnętrzne UE, regiony i polityka lokalna, scenariusze na przyszłość UE, wizerunek UE w mediach, bezpieczeństwo w UE, gospodarka unijna, rola kobiet w UE.

Ostatnim punktem programu był panel plenarny, podczas którego Dziekan WNPiD UAM - prof. dr hab. Tadeusz Wallas - dokonał podsumowania obrad prowadzonych $\mathrm{w}$ sesjach tematycznych, a następnie podsumował całą XIII Europejską Konferencję Naukowa, zauważając, że dzięki wieloperspektywicznym spostrzeżeniom, płynącym nie tylko $\mathrm{z}$ wystąpień, ale także $\mathrm{z}$ owocnych dyskusji, zrealizowano zamierzone cele konferencji, umożliwiając przy tym integrację środowiska badaczy oraz wymianę opinii i doświadczeń.

Krzysztof DUDA Magdalena MUSIAL-KARG Poznań 
